\title{
Reseña educativa sobre el papel de las políticas monetarias en la resiliencia económica de Irán y su vulnerabilidad para el auge de la producción
}

\section{Educational Examination on the Role of Monetary Policies in Iran's Economic Resilience and Vulnerability to Booming Production}

\author{
Mohsen Yadegari ${ }^{1}$, Farid Asgari ${ }^{2 a}$, Farzaneh Khalili $^{3}$ \\ Abhar Branch, Islamic Azad University, Abhar, Iran ${ }^{123}$ \\ Orcid ID: https://orcid.org/0000-0003-4311-1555 \\ Orcid ID: https://orcid.org/0000-0003-0621-4686 \\ Orcid ID: https://orcid.org/0000-0001-9715-621X ${ }^{3}$
}

Recibido: 25 de mayo de 2020

Aceptado: 12 de enero de 2021

\section{Resumen}

El objetivo de este estudio fue examinar el papel de las políticas monetarias (MP) en la resiliencia económica (RE) y la vulnerabilidad de Irán para el auge de la producción. Al hacerlo, se utilizaron los datos de Irán para el período 2017-2018. Se utilizó un método generalizado de momentos (GMM) para analizar los datos, y todos los análisis se realizaron con el software Eviews10. Los resultados indican que el PM y la política fiscal han afectado el índice ER de Irán, por lo que se sugiere que el gobierno allane el camino para fortalecer la resiliencia del país mejorando la eficiencia del sistema monetario y financiero del país. Los resultados indicaron que el MP y la política fiscal habían afectado a Irán, por lo que se sugiere que los responsables de la política económica del país intenten diseñar mecanismos de alerta para tomar medidas en la primera oportunidad para resolver la discrepancia en caso de cualquier inconsistencia en las políticas monetarias y fiscales que hacer al país más vulnerable. Finalmente, los resultados indicaron que el PM y la política fiscal habían afectado el índice ER neto de Irán; por lo tanto, se recomienda que los funcionarios monetarios y financieros del país especifiquen índices financieros como el estado presupuestario del gobierno e índices monetarios como la liquidez y tengan en cuenta las consecuencias de estas políticas en la RE neta del país.

Palabras clave: Resiliencia Económica, Vulnerabilidad Económica, Política Monetaria.

\footnotetext{
Abstract

${ }^{\text {a }}$ Corresponding Author: Email: asgari@aftermail.ir
}

The objective of this study was to examination of the role of monetary policies (MP) in Iran's economic resilience (ER) and vulnerability for the production boom. In doing so, Iran's data was 
used for the period 2017-2018. A generalized method of moments (GMM) method was used to analyze the data, and all the analyses were done using Eviews10 software. The results indicate that MP and fiscal policy have affected the Iran ER index, so it is suggested that the government pave the way for strengthening the country's resilience by enhancing the efficiency of the country's monetary and financial system. The results indicated that MP and fiscal policy had affected Iran, so it is suggested that the country's economic policymakers try to design warning mechanisms to take action at the earliest opportunity to resolve the discrepancy in the event of any inconsistency in monetary and fiscal policies that make the country more vulnerable. Finally, the results indicated that MP and fiscal policy had affected net ER index of Iran; thus, it is recommended that the country's monetary and financial officials specify financial indices like the government's budget status and monetary indices like liquidity and bear in mind the consequences of these policies on the country's net ER.

Keywords: Economic Resilience, Economic Vulnerability, Monetary Policy

\section{Introduction}

The global shocks due to oil prices, international financial crises, and global recessions in recent decades resulted in the entry of a concept called EV into the economic literature. Indeed, several countries suffered serious losses and faced economic and political shocks face with the stated international shocks and crises, making the degree of economic vulnerability to shocks significant. In spite of the existence of the above shocks, countries' ability to face shocks and their recovery, which shows their economies' resilience, were different: the ones with acceptable resilience levels could quickly digest shocks and return to their previous path. Hence, one can state that the opposite counterpart to the countries' EV is their ER (Taherpour, 2018).

Bates et al. (2014) divide resilience-vulnerability calculation indices into two categories. One is economic indices and governance, affecting other indices used as control dimensions. The second class of the indices was environmental, social, and peripheral indices that could not affect other indices independently, considered as conditional dimensions. Accordingly, four conditions have been classified for countries from worst to best: uncontrolled vulnerability, limited vulnerability, unsustainable resilience, and sustainable resilience. In the case of uncontrolled vulnerability, the values of the control and conditional dimensions will be negative, and thus, the net value of the vulnerability-resilience index will be negative. Limited vulnerability shows a state where the values of the control dimensions are greater than zero, and the values of the conditional dimensions are less than zero so that the net resilience-vulnerability index will be negative. In the case of unsustainable resilience, the values of the positive control dimensions, and the values of 
the conditional dimensions are negative, so that the net resilience-vulnerability index becomes more than zero. Sustainable resilience shows the ideal situation, where the values of control and conditional dimensions are positive, and thus the net value of the resilience-vulnerability index is positive (Bates et al., 2014).

The issue seen in both the resilience and vulnerability debates is the focus on macroeconomic indices and their effect on resilience and vulnerability indices. Thus, examining the relationship between macroeconomic indices and resilience and EV indices carefully is necessary. Among these indices is the MP (Bruneckiene et al, 2019). Regarding this, the study examines the effect of MPs on ER and vulnerability in Iran. The literature of the study will be presented. Later on, the theoretical foundations and empirical background will be presented. The model, variables, research method, and data analysis results will be presented, and finally, the conclusion will be presented.

\section{Literature review}

\section{Economic resilience}

ER can be defined differently, yet the term refers to the ability to recover or mitigate the negative effects of external economic shocks in this study. Resilience is defined as the ability to recover fast from the effects of an adverse event. In economic literature, the term refers to at least three types of abilities: a) rapid recovery from a shock, b) resistance to the effects of a shock, and c) preventing exposure to a shock (Ghiyashvannd and Abdolshah, 2015).

\section{Economic vulnerability}

Vulnerability is one of the structural features of a country that increases the weak points of the economy against exogenous shocks, and the vulnerability will deter long-term development. Vulnerability is defined as the capacity of a country to recover from a shock or to resist the effect of a shock (Angion and Bates, 2015).

\section{Monetary policy}

The policies that are used by the central bank to control liquidity are called MPs. The bank tries to affect the pattern of household consumption and enterprise production and finally, inflation by applying these policies. The most significant purpose of macroeconomic policies in general, and MPs are price stability, economic growth, and the desired level of employment. As realizing 
the ultimate goals is not readily achievable for policymakers, it is necessary to introduce intermediate goals and appropriate tools. In the MP case, the choice of intermediate target is often summed up in the choice between interest rate controls and money supply. In Iran, by pursuing an MP based on the control of monetary aggregates, it is tried to prevent disproportionate monetary expansion for liquidity and inflation contained in development programs besides providing the cash needed by manufacturing and investment sectors (Ehsani et al., 2017).

\section{Theoretical foundations}

Overall, the factors affecting EV and ER can be divided into four main areas based on the theory of economic resilience. To Briguglio et al (2003), these four areas are macroeconomic stability, market efficiency, proper management and supervision, and social development. The issue of financial policy is placed in the realm of macroeconomics, which is the focus of the present study.

Macroeconomic stability is the interaction between economic needs and demands. If the total cost of supply and demand is in equilibrium, the economy has an internal equilibrium, a stable financial position, a low inflation rate and an unemployment rate close to the normal rate, and at the same time an external equilibrium, where the volume of debt in the economy is low. These variables are strongly affected by the economic policies of governments and show how the government can cope with economic crises and sanctions (Jahanian, 2016). Overall, macroeconomics is based on three variables:

\section{Financial policies as budget deficits}

The status of the state budget is one of the most significant features as the result of financial and budgetary policies and one of the important tools for governments that can deal with the crises. A healthy financial status helps the government adjust its spending and finance policies when faced with crises. Iran is unable to comply with external shocks and sanctions, given its weak budget and tax policies. On the other hand, one of the biggest problems of Iran's economic system is the severe and long-term budget deficit caused by lack of proper planning, and the government has spent more than its income (Ardakani, 2017). For instance, during the lifetime of various governments, especially the ninth and tenth governments, the country's economic growth fluctuated drastically, which shows the lack of stability in the national economy. In 2005, at the beginning of the ninth government, economic growth reached 3.6\%, and the growth rate targeted 
for the implementation of the Fourth Development Plan was 8\%, but the previous trend was stopped with severe mismanagement, and the country's economy gradually moved backward. Even the increase in prices could not help economic stability, and gradually the country's export volume reduced, and even economic growth turned negative (Yumarni, 2018).

\section{High inflation and unemployment}

These two issues are significant indices, and these two rates show a budget deficit. This is because inflation and unemployment are affected by other economic policies and include monetary and supply policies. If the economy has a high rate of inflation and unemployment, in times of crisis like sanctions or economic shocks, these two indices increase, and in contrast, the economy where these two variables are low, is resistant to economic crises and shocks and does not increase welfare costs. In Iran, one of the main crises it has always faced is the control of inflation and the fight against unemployment, so that there are no suitable jobs for many graduates.

In other words, weaknesses in inflation and unemployment have weakened Iran's economy and mismanaged the resistance economy. According to the results obtained in 2016 from the statistical plans of the Statistics Center, the unemployment rate of the population for ten years and more in the whole country is $12.4 \%$, the growth rate of the active population (supply of labor) $1.1 \%$, the employed population (labor demand) $84.0 \%$, the unemployed population was $7.3 \%$, and the unemployment rate increased from $10.3 \%$ to $12.12 \%$. Concerning inflation, although it increased to $40 \%$ in the ninth and tenth governments and reduced in the eleventh government, it is still considered high. The main cause of the increase in inflation is the high volume of liquidity and the adoption of inappropriate MPs by the relevant authorities (Ardakani, 2017).

\section{Lack of knowledge-based economy}

A stable economy has to be able to create and generate knowledge, and on the other hand, all activities in the macroeconomics have to be transparent to provide common policies for competition in the international arena and to counter rising prices. Knowledge-based economics is composed of three main sections: 1) Economic stimuli and the structure of the institutions (dealing with customs barriers and tariffs, law enforcement), 2) matching new technologies and creating innovation, and 3) infrastructures of information and communication technology (ICT) (Rahrovani and Khosroshahi, 2016). 
Unfortunately, statistics show that Iran has made very little advancement in the cases stated from 2008 to 2017, ranking 95 out of 145 countries. The existence of many customs formalities, cumbersome rules, weakness in customs structures, and lack of supervision over the performance of this sector has created many problems for exporters and importers. In 2017, Iran ranked 78 in the knowledge-based economy, which has improved compared to previous statistics in previous years; however, there are still problems in this section (Heydari and Ahmadian, 2018).

\section{Inefficiency of markets in microeconomics}

Four main components are very effective in financial vulnerability among several components regarding the efficiency of markets in microeconomics:

The breadth and dominance of the government. The dimensions and size of a government are determined according to various factors like subsidies and transfers, and the percentage in GDP, the investment and tax revenue, and so on. Among the 157 countries in the world, Iran has ranked 99 in terms of government size. The government's share of the economy through consumption, investment and subsidies affects the private sector and can reduce the economy's resistance to crisis and sanctions by weakening the private sector and reducing free trade (Ardakani et al., 2014). Lack of free trade. This means that the government interferes in the international trade sector and renders the economy to lose its resilience against economic crises or shocks and fail to adapt to international trade patterns. Moreover, the sanctions prevent Iran from entering the global markets; for instance, $95 \%$ of the world's saffron is produced in Iran, but the lack of branding and the presence of Iranian companies in international markets have enabled the Spanish brand to replace Iran in this sector (Rahrovani et al., 2016).

Lack of proper supervision and management. Proper supervision and management are essential in an economic system to operate properly and be resilient at the same time. In this section, the management of intellectual property laws and rights is discussed. The absence of proper mechanisms in times of economic crisis and shock leads to social or economic chaos or makes it vulnerable. Indeed, the status of legal structures and creating security in intellectual property laws are the critical components of proper supervision and management, along with judicial independence, the impartiality of courts, protection of intellectual property rights, and the integrity of legal and political systems. Nonetheless, the gaps in the mentioned cases in Iran, as well as the long-term and persistent bureaucracy and the inability to reduce long-term administrative 
processes, have led to the collapse of the resistance economy. Regarding this, studies indicate that Iran has made no significant progress or changes, and not enough has been done in this regard from 2004 to 2014 (Pajouhandeh, 2015).

Low social development. Another component of resilience is social development, and its focus is on building social relationships properly and being able to operate the economic system. Social solidarity in such an economy means that social discourse occurs effectively in the economy. There are many indices for determining social development like income and its distribution, poor population rate, long-term unemployment rate, which shows that a part of a country's population has low skills or no permanent employment, or their level of education is low (Moghari, 2016).

\section{Research background}

Based on the studies done up to now, no studies have been done in Iran or other countries to study the effect of monetary and fiscal policies on resilience and EV to be presented in the previous studies section. Thus, only new studies on resilience and EV and related concepts are presented in this section. 


\section{Table 1}

Summary of previous studies

\begin{tabular}{|c|c|c|}
\hline $\begin{array}{l}\text { Researcher } \\
\text { (year) }\end{array}$ & Title & Results \\
\hline $\begin{array}{l}\text { Amiri et al. } \\
\text { (2018) }\end{array}$ & $\begin{array}{l}\text { Estimation of vulnerability and } \\
\text { resilience indices in the Iranian } \\
\text { economy }\end{array}$ & $\begin{array}{l}\text { Both the vulnerability and resilience have increased } \\
\text { in recent years, but the vulnerability more than the } \\
\text { resilience, showing an increase in the degree of } \\
\text { vulnerability in the Iranian economy. }\end{array}$ \\
\hline Moghari (2016) & $\begin{array}{l}\text { Measuring EV and ER in } \\
\text { selected OPEC member } \\
\text { countries }\end{array}$ & $\begin{array}{l}\text { EV is inversely related to ER and directly to GDP, } \\
\text { with the effect of ER more among the countries } \\
\text { studied. }\end{array}$ \\
\hline $\begin{array}{l}\text { Ghiasvand and } \\
\text { Abdolshah } \\
\text { (2015) }\end{array}$ & ER indices & $\begin{array}{l}\text { A social system is resilient when it can absorb } \\
\text { temporary or permanent risks and adapt to rapidly } \\
\text { changing conditions without losing its function. }\end{array}$ \\
\hline $\begin{array}{l}\text { Bruneckiene et } \\
\text { al. (2019) }\end{array}$ & $\begin{array}{l}\text { Evaluation of resilience of the } \\
\text { socio-economic system } \\
\text { relative to economic shocks }\end{array}$ & $\begin{array}{l}\text { The results indicate that economic shocks have } \\
\text { affected the resilience of the socio-economic system. }\end{array}$ \\
\hline $\begin{array}{l}\text { Oliva and Lazarti } \\
\text { (2018) }\end{array}$ & $\begin{array}{l}\text { Measuring the EV of Natural } \\
\text { Stress for Japan }\end{array}$ & $\begin{array}{l}\text { The paper tries to strengthen the debate on regional } \\
\text { economic flexibility against natural disasters by } \\
\text { building resilience and recovery indices for Japanese } \\
\text { prefect affected by major earthquakes. }\end{array}$ \\
\hline $\begin{array}{l}\text { Bastamnia et al. } \\
\qquad(2018)\end{array}$ & $\begin{array}{l}\text { Identification and evaluation } \\
\text { of components and factors } \\
\text { affecting economic and social } \\
\text { resilience in Rudbar, Iran }\end{array}$ & $\begin{array}{l}\text { Social resilience increases with length of stay in the } \\
\text { neighborhood, the number of educated family } \\
\text { members, and the level of higher education of the } \\
\text { head of the household, the number of unemployed } \\
\text { people, and the number of physically and mentally } \\
\text { disabled people in the family, and the ownership of a } \\
\text { house compared to being a tenant. }\end{array}$ \\
\hline $\begin{array}{l}\text { Angion and Bates } \\
\qquad(2018)\end{array}$ & $\begin{array}{l}\text { Comparison of vulnerability } \\
\text { index between less developed } \\
\text { and developed countries }\end{array}$ & $\begin{array}{l}\text { Developed countries have high resilience and less } \\
\text { developed countries have high vulnerability }\end{array}$ \\
\hline Bates et al. (2017) & $\begin{array}{l}\text { Examining resilience and } \\
\text { vulnerability in Singapore }\end{array}$ & $\begin{array}{l}\text { Singapore resilience is greater than its vulnerability. } \\
\text { Moreover, it has been observed that resilience is the } \\
\text { result of good government and the benefits of global } \\
\text { integration }\end{array}$ \\
\hline Sabatino (2017) & $\begin{array}{l}\text { Economic crises and shocks } \\
\text { and ER: the resilience capacity } \\
\text { and competitiveness of } \\
\text { companies }\end{array}$ & $\begin{array}{l}\text { Ultimately, this study can provide a new } \\
\text { management culture according to the principles of } \\
\text { adaptation, resilience, and innovation }\end{array}$ \\
\hline
\end{tabular}

According to the points stated in the previous sections, the following hypotheses are presented in the study: 
Hypothesis 1: The effect of MP on the Iran ER index is significant.

Hypothesis 2: The effect of MP on the Iran EV index is significant.

Hypothesis 3: The effect of MP on the Iran net ER index is significant.

\section{Methodology}

The study was applied in terms of purpose since its results can be used in the decisions of major national authorities. Furthermore, it was descriptive-correlational regarding inference on research hypotheses, as the correlation coefficient of regression techniques were used to find the relationships between the variables. Moreover, as we concluded by testing the available data, it was cross-sectional. The data collection method was the library method.

The following regression models were used to examine the effect of MP on ER and EV indices. The modeling process for resilience and vulnerability indices is as follows:

$\mathrm{RES}_{\mathrm{t}}=\mathrm{c} 0+\mathrm{c} 1 \mathrm{IR}_{\mathrm{t}}+\mathrm{c} 2 \mathrm{LR}_{\mathrm{t}}+\mathrm{c} 3 \mathrm{LIQ}_{\mathrm{t}}+\mathrm{c} 4 \mathrm{GEXP}_{\mathrm{t}}+\mathrm{c} 5 \mathrm{TR}_{\mathrm{t}}+\mathrm{c} 6$ Deficit $_{\mathrm{t}}+\mathrm{c} 7 \mathrm{DEBT}_{\mathrm{t}}+\mathrm{c} 8$ Governence $_{t}+\mathrm{c} 9$ Development $_{t}+\mathrm{c} 10 \mathrm{GDP}_{\mathrm{t}}+\mathrm{c} 11 \mathrm{INF}_{\mathrm{t}}+\mathrm{c} 12 \mathrm{OPEEN}_{\mathrm{t}}+\mathrm{c} 13 \mathrm{DUM}_{\mathrm{t}}+\mathrm{c} 14$ DUM2 $t+c 15$ DUM3 $t+e_{t}$

$\mathrm{VUL}_{\mathrm{t}}=\mathrm{c} 0+\mathrm{c} 1 \mathrm{IR}_{\mathrm{t}}+\mathrm{c} 2 \mathrm{LR}_{\mathrm{t}}+\mathrm{c} 3 \mathrm{LIQ}_{\mathrm{t}}+\mathrm{c} 4 \mathrm{GEXP}_{\mathrm{t}}+\mathrm{c} 5 \mathrm{TR}_{\mathrm{t}}+\mathrm{c} 6$ Deficit $_{\mathrm{t}}+\mathrm{c} 7 \mathrm{DEBT}_{\mathrm{t}}+\mathrm{c} 8$ Governence $_{t}+\mathrm{c} 9$ Development $_{t}+\mathrm{c} 10 \mathrm{GDP}_{\mathrm{t}}+\mathrm{c} 11 \mathrm{INF}_{\mathrm{t}}+\mathrm{c} 12 \mathrm{OPEEN}_{\mathrm{t}}+\mathrm{c} 13 \mathrm{DUM}_{\mathrm{t}}+\mathrm{c} 14$ DUM2 $t+c 15$ DUM $3 t+e_{t}$

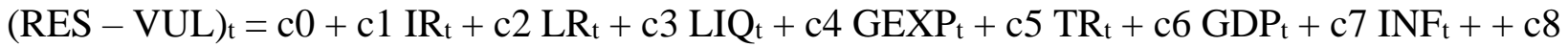
Governence $t_{t}+\mathrm{c} 9$ Development $_{\mathrm{t}}+\mathrm{c} 10 \mathrm{GDP}_{\mathrm{t}}+\mathrm{c} 11 \mathrm{INF}_{\mathrm{t}}+\mathrm{c} 12 \mathrm{OPEEN}_{\mathrm{t}}+\mathrm{c} 13 \mathrm{DUM}_{\mathrm{t}}+\mathrm{c} 14$ $\mathrm{DUM} 2 \mathrm{t}+\mathrm{c} 15 \mathrm{DUM} 3 \mathrm{t}+\mathrm{e}_{\mathrm{t}}$

\section{Dependent variables:}

ER Index (RES): Considering the data limitation for Iran, as well as following Briguglio et al. (2006), the weighted average variables of the budget deficit, government size, economic freedom index, and education index were used as indices for ER.

EV Index (VUL): Considering data limitation for Iran, as well as following Briguglio (2003), economic openness was used as an index of EV, calculated by dividing the total exports and imports by GDP. 


\section{Independent variables}

MP index includes interest rates (IR), legal deposit rate (LR), and liquidity (LIQ), which are interest rates on one-year deposits of state-owned banks, legal deposit rates of banks, and banknotes and coins and visuals are defined and calculated.

\section{Control variables}

Financial policy index includes government expenditures (GEXP), consumption and development expenditures, government tax revenues (TR), the ratio of budget deficit to GDP (Deficit), and the ratio of debt to GDP (DEBT).

Gross domestic product (GDP) is defined as the country's annual economic growth rate.

Governance index as a rule of law index published annually by the International Transparency Organization, as well as the Social Development Index as a literacy rate, are also independent research variables.

Inflation rate (INF) defined and calculated as the annual inflation rate of the country

The degree of trade openness (OPEEN) defined as the sum of exports and imports divided by the country's GDP

DUM1 shows the virtual variable related to Donald Trump's presidency, which will be zero for 2016, which is before his presidency, and one for the time later.

DUM2 shows the dummy variable of the Joint Comprehensive Plan of Action (JCPOA), which is zero for 2015 (the year of signing JCPOA) and one for later on.

DUM3 shows the dummy variable of the resistance economy, which is one for 2013 when the general policies of the resistance economy were first proposed by the Leader of the Revolution, and zero for previous years.

\section{Parameter c0 shows the constant value or $y$-intercept in the model}

The database of the Central Bank, the Statistics Center of Iran, the World Bank, and the UNCTAD database were used to measure the indices. A 37-year period from 1982 and 2018 was selected to examine hypothesis testing. It has to be noted that all calculations and analyses were done in Excel and 10Eviews. GMM was used to analyze the information. 


\section{Results}

Variables stationary

In this section, the stationarity of the variables and their tests are discussed. Augmented Dickey-Fuller test (ADF) was used for this purpose.

\section{Table 2}

The results of variables stationarity test

\begin{tabular}{cccc}
\hline Variables & t statistic & Probability & Result \\
\hline RES & -2.39 & 0.0248 & Stationary \\
VUL & -4.33 & 0.0001 & Stationary \\
RESVUL & -3.39 & 0.0000 & Stationary \\
IR & -4.10 & 0.0168 & Stationary \\
LR & -4.18 & 0.0113 & Stationary \\
LIQ & -4.29 & 0.0022 & Stationary \\
GEXP & -2.28 & 0.0173 & Stationary \\
TR & -5.58 & 0.0000 & Stationary \\
DEFICIT & -2.08 & 0.0372 & Stationary \\
DEBT & -2.22 & 0.0295 & Stationary \\
GOVERNENCE & -2.71 & 0.0000 & Stationary \\
DEVELOPMENT & -3.79 & 0.0369 & Stationary \\
GDP & -5.71 & 0.0002 & Stationary \\
INF & -3.49 & 0.0548 & Stationary \\
OPEEN & -8.35 & 0.0000 & Stationary \\
\hline
\end{tabular}

Source: Research Findings

As the significance level of the test for all variables is less than 0.10 , we reject the assumption that there is a single root in the series, and the data are stationary at $90 \%$ significance.

\section{Testing research hypotheses}

$\mathrm{RES}_{\mathrm{t}}=\mathrm{c} 0+\mathrm{c} 1 \mathrm{IR}_{\mathrm{t}}+\mathrm{c} 2 \mathrm{LR}_{\mathrm{t}}+\mathrm{c} 3 \mathrm{LIQ}_{\mathrm{t}}+\mathrm{c} 4 \mathrm{GEXP}_{\mathrm{t}}+\mathrm{c} 5 \mathrm{TR}_{\mathrm{t}}+\mathrm{c} 6$ Deficit $_{\mathrm{t}}+\mathrm{c} 7 \mathrm{DEBT}_{\mathrm{t}}+\mathrm{c} 8$ Governence $\mathrm{t}+\mathrm{c}$ 9 Development $\mathrm{t}+\mathrm{c} 10 \mathrm{GDP}_{\mathrm{t}}+\mathrm{c} 11 \mathrm{INF}_{\mathrm{t}}+\mathrm{c} 12$ OPEEN $_{\mathrm{t}}+\mathrm{c} 13 \mathrm{DUM}_{\mathrm{t}}+\mathrm{c} 14$ DUM2 $t+c 15$ DUM $3 t+e_{t}$ 


\section{Table 3}

The results of regression analysis of resilience model

\begin{tabular}{|c|c|c|c|c|}
\hline Index & Abbreviation & Coefficient & t statistic & Probability \\
\hline Interest rate & IR & -131.5875 & -1.425090 & 0.1682 \\
\hline Legal deposit rate & LR & 9.848780 & 0.392746 & 0.6983 \\
\hline Liquidity & LIQ & -339.9687 & -2.709416 & 0.0128 \\
\hline Government expenses & GEXP & -1143.449 & -2.488184 & 0.0209 \\
\hline Tax revenue & TR & 1416.916 & 3.019756 & 0.0063 \\
\hline Deficit & DEFICIT & 0.951980 & 1.490442 & 0.1503 \\
\hline Debt ratio & DEBT & -42.04341 & -1.148715 & 0.2630 \\
\hline Good governance & GOVERNENCE & 135.3936 & 1.007971 & 0.3244 \\
\hline Social Development & DEVELOPMENT & -61.12493 & -0.332981 & 0.7423 \\
\hline $\begin{array}{l}\text { Economic Growth (gross domestic } \\
\text { production) }\end{array}$ & GDP & 26.09257 & 1.696976 & 0.1038 \\
\hline The inflation rate & INF & 19.63872 & 0.818854 & 0.4217 \\
\hline Commercial openness & OPEEN & 14.36035 & 0.514737 & 0.6119 \\
\hline President Trump & DUM1 & -130.8927 & -2.145338 & 0.0432 \\
\hline JCPOA & DUM2 & 27.98722 & 0.664501 & 0.5133 \\
\hline Economic Strength & DUM3 & 100.3062 & 3.387224 & 0.0027 \\
\hline Model determination coefficient & $R^{2}$ & 0.92 & & \\
\hline $\begin{array}{c}\text { Modified determination coefficient } \\
\text { of the model }\end{array}$ & Adj-R2 & 0.87 & $\begin{array}{l}\text { Durbin- } \\
\text { Watson }\end{array}$ & 2.46 \\
\hline Model goodness of fit & J statistic & 5.46 & Sig. & 0.0649 \\
\hline
\end{tabular}

Source: Research findings

The above table shows that as $\mathbf{J}$ statistic has a probability less than the significance level $10 \%$, the significance of the whole regression model and the instrumental variables used in the model are confirmed. Moreover, the value of the coefficient of determination shows that about $92 \%$ of the dependent variable changes are explained by independent and control variables, showing a high explanatory power. In sum, the results of estimating the main research model show that:

- IR has an effect of 131.58 units on the dependent variable (ER index), which has been negative and insignificant so that 131.58 units of changes in the ER index is explained by changes in the interest rate.

- LR has an effect of 9.84 units on the dependent variable (ER index), which has been positive and insignificant so that 9.84 units of changes in the ER index are explained by the changes in the LR variable. 
- LIQ has an effect of 339.96 units on the dependent variable (ER index), which has been negative and significant so that 399.96 units of changes in the ER index are explained by changes in liquidity.

$\mathrm{VUL}_{\mathrm{t}}=\mathrm{c} 0+\mathrm{c} 1 \mathrm{IR}_{\mathrm{t}}+\mathrm{c} 2 \mathrm{LR}_{\mathrm{t}}+\mathrm{c} 3 \mathrm{LIQ}_{\mathrm{t}}+\mathrm{c} 4 \mathrm{GEXP}_{\mathrm{t}}+\mathrm{c} 5 \mathrm{TR}_{\mathrm{t}}+\mathrm{c} 6$ Deficit $_{\mathrm{t}}+\mathrm{c} 7 \mathrm{DEBT}_{\mathrm{t}}+\mathrm{c} 8$ Governence $_{t}+\mathrm{c} 9$ Development $t+c 10 \mathrm{GDP}_{t}+\mathrm{c} 11 \mathrm{INF}_{\mathrm{t}}+\mathrm{c} 13 \mathrm{DUM} 1_{\mathrm{t}}+\mathrm{c} 14 \mathrm{DUM} 2_{\mathrm{t}}+\mathrm{c} 15$ DUM3 $3_{t}+e_{t}$

\section{Table 4}

The results of regression analysis of vulnerability model

\begin{tabular}{|c|c|c|c|c|}
\hline $\begin{array}{ll}\text { Variable } & \text { Index } \\
\text { Valla }\end{array}$ & Abbreviation & Coefficient & t statistic & Probability \\
\hline Interest rate & IR & 2.508130 & 7.269187 & 0.0000 \\
\hline Legal deposit rate & LR & -0.453217 & -3.350777 & 0.0028 \\
\hline Liquidity & LIQ & -1.979378 & -4.861450 & 0.0001 \\
\hline $\begin{array}{l}\text { Government } \\
\text { expenses }\end{array}$ & GEXP & 7.982122 & 5.948372 & 0.0000 \\
\hline Tax revenue & $\mathrm{TR}$ & -4.413954 & -3.465976 & 0.0021 \\
\hline Deficit & DEFICIT & -0.003515 & -1.501522 & 0.1468 \\
\hline Debt ratio & DEBT & -0.628119 & -2.515820 & 0.0193 \\
\hline Good governance & GOVERNENCE & 3.276419 & 12.83667 & 0.0000 \\
\hline $\begin{array}{c}\text { Social } \\
\text { Development }\end{array}$ & DEVELOPMENT & -4.254920 & -9.702942 & 0.0000 \\
\hline $\begin{array}{l}\text { Economic Growth } \\
\text { (gross domestic }\end{array}$ & GDP & & & \\
\hline production) & & 0.002851 & 0.046518 & 0.9633 \\
\hline The inflation rate & INF & -0.146429 & -2.181888 & 0.0396 \\
\hline $\begin{array}{c}\text { Commercial } \\
\text { openness }\end{array}$ & OPEEN & -1.016630 & -1.204937 & 0.2410 \\
\hline President Trump & DUM1 & 0.015917 & 0.093019 & 0.9267 \\
\hline JCPOA & DUM2 & -1.294871 & -10.12906 & 0.0000 \\
\hline $\begin{array}{c}\text { Economic Strength } \\
\text { Model }\end{array}$ & DUM3 & 0.419100 & 3.093559 & 0.0051 \\
\hline $\begin{array}{c}\text { determination } \\
\text { coefficient }\end{array}$ & $R^{2}$ & 0.88 & & \\
\hline $\begin{array}{c}\text { Modified } \\
\text { determination } \\
\text { coefficient of the } \\
\text { model }\end{array}$ & Adj-R2 & 0.82 & $\begin{array}{l}\text { Durbin- } \\
\text { Watson }\end{array}$ & 2.14 \\
\hline $\begin{array}{l}\text { Model goodness of } \\
\text { fit }\end{array}$ & $\mathrm{J}$ statistic & 5.63 & Sig. & 0.0597 \\
\hline
\end{tabular}

Source: Research Findings 
The table above shows that as $\mathrm{J}$ statistic is less than the significance level $10 \%$, the significance of the whole regression model and the instrumental variables used in the model are confirmed. Moreover, the value of the determination coefficient shows that about $88 \%$ of the dependent variable changes are explained by the independent and control variables, showing the high explanatory power of the study. In sum, the results of estimating the main research model show that:

- IR has an effect of 2.50 units on the dependent variable (EV index), which has been a positive and significant effect so that 2.50 units of changes in EV are explained by IR.

- LR has an effect of 0.45 units on the dependent variable (EV Index), which has been negative and significant so that 0.45 units of changes in $\mathrm{EV}$ are explained by changes in LR.

- LIQ has an effect of 1.97 units on the dependent variable (EV index), which has been negative and significant so that 1.97 units of changes in EV are explained by changes in liquidity.

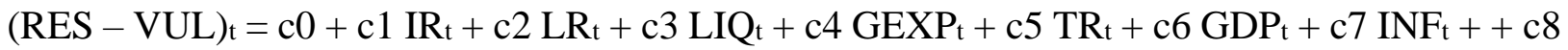
Governence $_{t}+\mathrm{c} 9$ Development $_{\mathrm{t}}+\mathrm{c} 10 \mathrm{GDP}_{\mathrm{t}}+\mathrm{c} 11 \mathrm{INF}_{\mathrm{t}}+\mathrm{c} 12 \mathrm{OPEEN}_{\mathrm{t}}+\mathrm{c} 13 \mathrm{DUM}_{\mathrm{t}}+\mathrm{c} 14$ DUM2 ${ }_{t}+\mathrm{c} 15$ DUM3 ${ }_{t}+e_{t}$ 


\section{Table 5}

The results of regression analysis of net resilience model

\begin{tabular}{ccccc}
\hline Index & Abbreviation & Coefficient & t statistic & Probability \\
Variable & & & \\
\hline Interest rate & IR & -97.03280 & -1.355886 & 0.1883 \\
Legal deposit rate & LR & 0.708321 & 0.032480 & 0.9744 \\
Liquidity & LIQ & -438.8801 & -2.996463 & 0.0064 \\
Government expenses & GEXP & -1063.889 & -2.449481 & 0.0223 \\
Tax revenue & TR & 1476.544 & 3.330843 & 0.0029 \\
Deficit & DEFICIT & 1.161836 & 2.227461 & 0.0360 \\
Debt ratio & DEBT & -54.49715 & -1.716113 & 0.0996 \\
Good governance & GOVERNENCE & 211.0262 & 2.628891 & 0.0150 \\
Social Development & DEVELOPMENT & -151.0234 & -1.252226 & 0.2231 \\
Economic Growth (gross & GDP & 32.30506 & 2.551220 & 0.0179 \\
domestic production) & INF & 19.89985 & 1.173361 & 0.2527 \\
The inflation rate & OPEEN & 3.118377 & 6.584471 & 0.0000 \\
Commercial openness & DUM1 & -144.0142 & -2.432103 & 0.0232 \\
President Trump & DUM2 & -6.886529 & -0.243237 & 0.8100 \\
JCPOA & DUM3 & 117.7937 & 3.496818 & 0.0019 \\
Economic Strength & $R^{2}$ & 0.92 & & \\
Model determination & & & & 2.41 \\
coefficient & Adj-R2 & 0.87 & Durbin-Watson & \\
Modified determination & J statistic & 5.31 & Sig. & 0.0702 \\
coefficient of the model & & & \\
Model goodness of fit & & & & \\
\hline
\end{tabular}

Source: Research Findings

The table above shows that as $\mathrm{J}$ statistic is less than the significance level $10 \%$, the significance of the whole regression model and the instrumental variables used in the model are confirmed. Moreover, the value of the determination coefficient shows that about $92 \%$ of the dependent variable changes are explained by the independent and control variables, showing the high explanatory power of the study. In sum, the results of estimating the main research model show that:

-IR has an effect of 97.03 units on the dependent variable (ER index), which has been a negative and significant effect so that 97.03 units of changes in ER are explained by IR .

-LR has an effect of 0.70 units on the dependent variable (ER Index), which has been positive and insignificant so that 0.70 units of changes in ER are explained by changes in LR. 
- LIQ has an effect of 438.88 units on the dependent variable (ER index), which has been negative and significant so that 438.88 units of changes in ER are explained by changes in liquidity.

- GEXP has an effect of 1063.88 units on the dependent variable (ER index), which has been negative and significant so that 1063.88 units of changes in ER are explained by changes in GEXP.

- TR has an effect on the dependent variable (net ER index) by 1476.54 units, which has been a positive and significant effect so that 1476.54 units of changes in the net ER are explained by the changes in TR.

\section{Diagnostic tests}

Test of the normality of the error component

Table 6 shows the statistical value and significance of the Jarque-Bera statistic for the error component of the models estimated above.

\section{Table 6}

The results of Jarque-Bera test

\begin{tabular}{cccc}
\hline Model & $\begin{array}{c}\text { Jarque-Bera } \\
\text { statistic }\end{array}$ & Probability & Results \\
\hline Resilience & 0.49 & 0.7805 & Normal \\
Vulnerability & 0.46 & 0.7915 & Normal \\
Net resilience & 0.49 & 0.7805 & Normal \\
\hline
\end{tabular}

Source: Research findings

In the normality test, the null hypothesis states that the expression is part of the error of the models estimated is normal. As Jarque-Bera statistic for the expression is an error component of the models estimated in the study greater than 0.10 , the null hypothesis stating the normality of error component in the models estimated in confirmed.

\section{Error component collinearity test}

The results of collinearity of LM test are presented in the table below: 


\section{Table 7}

The results of LM collinearity of error component

\begin{tabular}{cccc}
\hline Model & $\begin{array}{c}\text { Breusch-Pagan } \\
\text { test }\end{array}$ & Probability & Results \\
\hline Resilience & 0.16 & 0.8528 & Collinearity \\
Vulnerability & 0.11 & 0.7476 & Collinearity \\
Net resilience & 0.16 & 0.8528 & Collinearity \\
\hline
\end{tabular}

Source: Research findings

In the collinearity test, the null hypothesis states that the residual components of the regression model lack strong collinearity. As the LM statistic has a probability of more than 0.10 , it suggests that the assumption that there is no sharp linearity for the remaining components of the regression model is confirmed.

\section{Variance heterogeneity test of the error component}

Table 8 shows the results of the analysis of variance similarity using Breusch-Pagan test.

\section{Table 8}

Test results of variance heterogeneity of the research models

\begin{tabular}{cccc}
\hline Model & Statistics & Probability & Results \\
\hline Resilience & $1.56 / 1$ & 0.1680 & $\begin{array}{c}\text { Heterogeneity of } \\
\text { variance } \\
\text { Vulnerability }\end{array}$ \\
Net resilience & 1.24 & 0.3139 & $\begin{array}{c}\text { Heterogeneity of } \\
\text { variance } \\
\text { Heterogeneity of } \\
\text { variance }\end{array}$ \\
\hline
\end{tabular}

Source: Research findings

The results in Table 4-6 show that the probability of the statistical calculation calculated in the heterogeneity variance test is inconsistent for the larger research models greater than 0.10 , so the $\mathrm{H}_{0}$ hypothesis of this test based on the variance similarity is not rejected. 


\section{Structural failure test}

CUSUM test is used to diagnose a structural failure in the study. The results of this test are presented in the following diagrams:

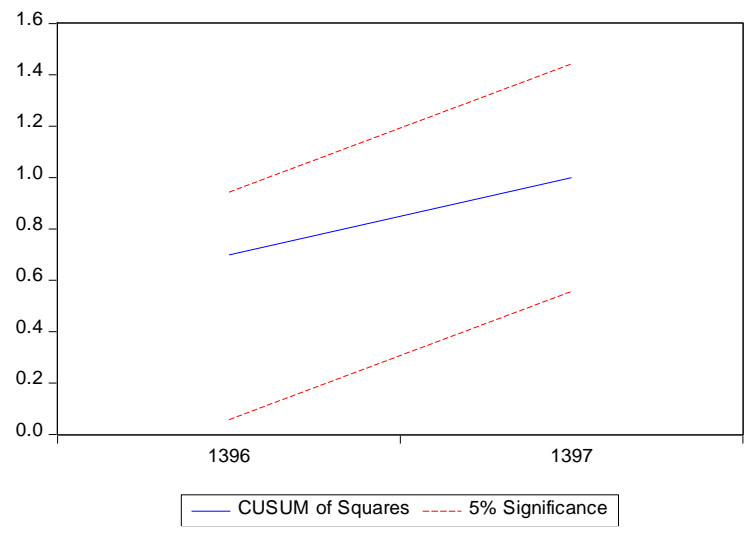

Figure 1

Structural failure test for resilience model Source: Research findings

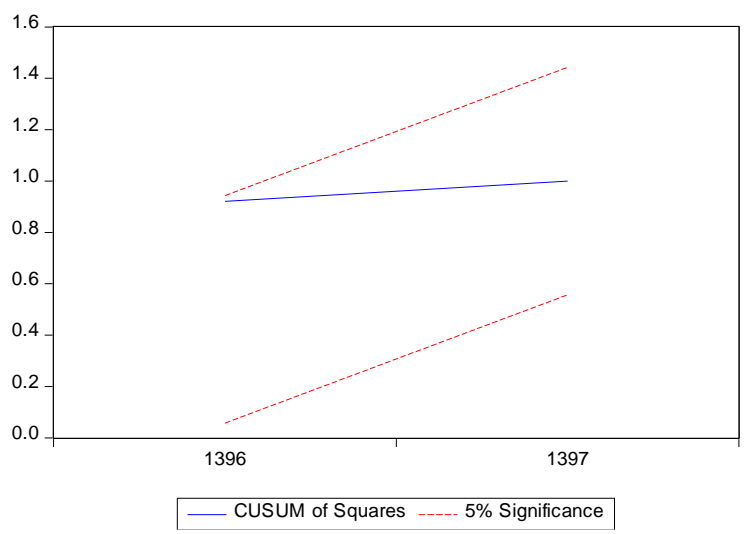

Figure 2

Structural failure test for vulnerability model Source: Research findings 


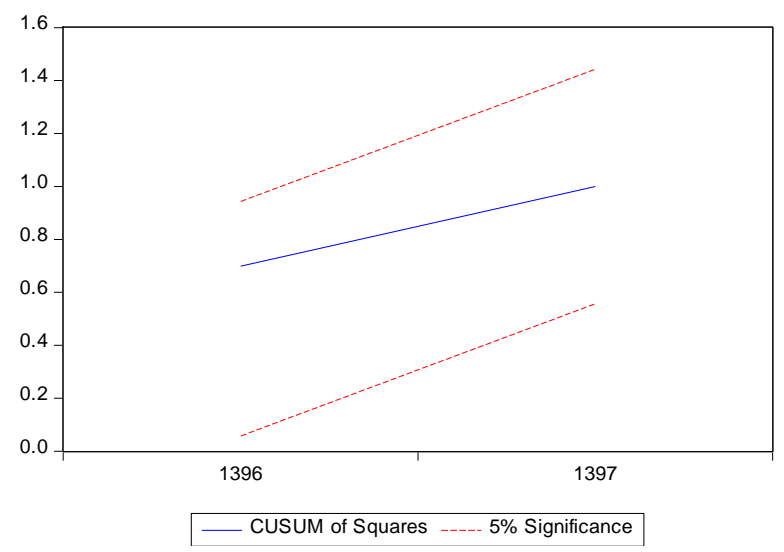

Figure 3

Structural failure test for net resilience model

Source: Research findings

The results in the graphs above show that the estimated models are stable as the probability of CUSUM (blue line) is within a significant range of 5\% (red lines).

\section{Discussion}

The purpose of this study was to examination of the role of monetary policies (MP) in Iran's economic resilience (ER) and vulnerability for the production boom. Among the limitations that we had in this study are the lack of available statistics and information and its confidentiality, lack of transparency in the Iranian monetary and banking system, lack of access to classified data, lack of cooperation of related organizations.

In relation to the hypothesis 1 , it was observed that the effect of MP on the Iran ER index is significant. The results showed that from among the three indices - IR, LR, and liquidity - the liquidity has significant effects on the resilience index in Iran during the study period (coefficient of 339.96 with a probability of 0.0128 ). Thus, the null hypothesis is rejected, and the opposite hypothesis is confirmed: there is a significant relationship between MP index and ER. Thus, the first hypothesis was not rejected. Regarding this, it is stated that indices like IR, LR, and liquidity, which are the main tools of MP, will have a significant effect on the fragility of the country's financial and banking system, which can thus affect ER of the country. Thus, the existence of a significant relationship between MP and ER is theoretically confirmed. 
This conclusion is in line with those of Amiri et al. (2018), Bakhtiari, and Sajjadieh (2018).

In relation to the hypothesis 2, it was observed that the effect of MP on the Iran EV index is significant. The results showed that three indices - IR, LR, and liquidity - have significant effects on the vulnerability in Iran during the study period (respectively, coefficient 2.50 with a probability of 0.0000 , coefficient 0.45 with a probability of 0.0028 and a coefficient of 1.97 with a probability of 0.0001). Thus, the null hypothesis is rejected, and the opposite assumption - there is a significant relationship between MP index and vulnerability - is confirmed. Thus, the third hypothesis is not rejected. Regarding this, it is stated that as the government has a critical and varied role in the Iranian economy, government policies as MP have a great role in the real sector of the economy that can make the country more vulnerable to external damage. Hence, the existence of a significant relationship between MP and EV is theoretically confirmed.

This is in line with those of Amiri et al. (2018), Bakhtiari and Sajjadieh (2018).

Finally, as for the hypothesis hypothesis 3, the effect of MP on the net economic index of Iran resilience is significant. The results showed that from among the three indices - IR, LR, and liquidity - liquidity has significant effects on the net resilience index in Iran during the study period (coefficient 438,88 with a probability of 0.0064 ). Thus, the null hypothesis is rejected, and the opposite assumption - there is a significant relationship between MP index and net ER - is confirmed. Hence, the fifth hypothesis is not rejected. Regarding this, it is stated that the more the central bank has created more credibility through measures like successful inflation control, injecting money into the market during the recession, and so on, these measures will create more space to facilitate MP or support economic activities. Thus, the country's resistance to the crisis will increase during the recession, and net resilience will increase. Therefore, the existence of a 
significant relationship between MPs and net resilience is theoretically confirmed. This is in line with those of Amiri et al. (2018), Bakhtiari and Sajjadieh (2018).

\section{Conclusion}

All these results indicate that MP and fiscal policy have affected the Iran ER index, so it is suggested that the government pave the way for strengthening the country's resilience by enhancing the efficiency of the country's monetary and financial system. The results indicated that MP and fiscal policy had affected Iran EV, so it is suggested that the country's economic policymakers try to design warning mechanisms to take action at the earliest opportunity to resolve the discrepancy in the event of any inconsistency in monetary and fiscal policies that make the country more vulnerable.

Also, the results indicated that MP and fiscal policy had affected net ER index of Iran; thus, it is recommended that the country's monetary and financial officials specify financial indices like the government's budget status and monetary indices like liquidity and bear in mind the consequences of these policies on the country's net ER.

\section{References}

Briguglio, L., Galea, W. (2003). Updating and Augmenting the Economic Vulnerability Index. Occasional Reports on Islands and Small States, No 2004/4, USA. https://www.um.edu.mt/library/oar/handle/123456789/18371

Ehsani, M. A., Keshavarz, H., Keshavarz, M. (2017). The Effect of Monetary and Financial Policies on Employment Fluctuations with Emphasis on Private Sector Employment. Economic Growth and Development Research, 7(26), 125-144. http://journals.pnu.ac.ir/article_3111.html

Ghiasvand, A., Ramezanian, E. (2015). Evaluation of Iran's ER during the period 1996-2013. Basij Strategic Studies Quarterly, 68, 79-88. http://www.bsrq.ir/

Heidari, H., Ahmadian, A. (2018). Monetary Inflation Requirements: Banks' Financial Health Vulnerability. Monetary and Banking Research, 8(26), 481-498. http://conf.mbri.ac.ir/conf25/userfiles/file/\%D8\%A7\%D8\%B3\%D9\%84\%D8\%A7\%DB $\% 8 \mathrm{C} \% \mathrm{D} 8 \% \mathrm{AF} \% \mathrm{D} 9 \% 87 \% \mathrm{D} 8 \% \mathrm{~A} 7 /$ ahmadian-heydar-conf25.pdf 
Jahanian, M. (2016). The role of government in the development of Iran's tourism economy with a focus on the resistance economy. Journal of Tourism and Development, 5(9), 156-177. http://www.itsairanj.ir/article_46223_27c5aa28f341532d56a3479045802fff.pdf

Lajevardi, H., Abunouri, E., Beshartirad, Z. (2017). Estimation of the ER Index in Iran and presentation of improvement strategies. International Conference on Urban Economics, Tehran. Iran. https://civilica.com/doc/510555/

Moghari, M. (2016). Measuring EV and ER in Selected OPEC Member Countries. M.Sc Thesis, Allameh Tabatabai University, Tehran. Iran. https://jem.atu.ac.ir/

Mohammad Hossein, M. (2016). Resistance Economy and Ways to Achieve This Goal. International Journal of Humanities and Cultural Studies (IJHCS), 3(1), 2685-2690. https://www.ijhcs.com/index.php/ijhcs/article/view/2900

Pajouhandeh, M. H. (2015). Obstacles to the Realization of the Resistance Economy. Islamic Social Research, 21, 185-239. https://www.sid.ir/fa/journal/ViewPaper.aspx?ID=254392

Rahravani, H., Khoshkalam Khosroshahi, M. (2016). The Resistance Economy and Strategy of the Islamic Republic of Iran to Confront the Hostile Approaches of the United States and Saudi Arabia in the Oil Market. Quarterly Journal of Financial and Economic Policy, 4(15), 4370. http://qjfep.ir/article-1-455-fa.html

Ranjbar Ardakani, S. (2017). Obstacles to the Realization of the Resistance Economy in the Islamic Republic of Iran. Quarterly Journal of Islamic Research Approach, 11(39), 141160. http://www.rahyaft.info/article_51256.html

Sadegh. B., Farzam, S. (2018). Theoretical and Empirical Analysis of ER Index. Iranian Journal of Economic Studies, 7(1),41-53. https://aes.basu.ac.ir/

Stefania, O., Luciana, L. (2018). Measuring the ER of natural disasters: An analysis of major earthquakes in Japan. City, Culture and Society, 15, 53-59. 10.1016/j.ccs.2018.05.005

Taherpour, J. (2018). The effectiveness of labor productivity on ER and vulnerability. Quarterly Journal of Economic Modeling Research, 31, 56-69. https://jemr.khu.ac.ir/browse.php?a_code=A-10-1999-1\&slc_lang=fa\&sid=1

Tan, J., Zhang, P., Lo, K., Li, J., Liu, S. (2017). Conceptualizing and Measuring ER of ResourceBased Cities: Case Study of Northeast China. Chinese Geographical Science, 27(3), 471481. $10.1007 / \mathrm{s} 11769-017-0878-6$ 
Tarik, D., Elizabeth, A., Marchio, U. B., Courtney, S. (2019). Climate change: Vulnerability and resilience of tourism and the entire economy. Tourism Management, 72, 292-305. $\underline{10.1016 / j . t o u r m a n .2018 .12 .010}$

Tri, Y. (2018). Ten years later: ER of small scale enterprise following earthquake in Bantul $\begin{array}{llll}\text { Yogyakarta, } \quad \text { Procedia } \quad \text { Engineering, } & \text { 309-315. }\end{array}$ https://doi.org/10.1016/j.proeng.2018.01.040 